\title{
蝸牛呼吸系に関する検討 ニモルモット螖牛の
}

\section{内リンパ腔開放に依る酸素消費の変動について}

蝸牛の酸素消費量の測定は，聴覚機構の基本 現象を知る上に必要である。しかし予め検討を 要する二つの問題がある。第一に膜蝸牛の全体 としての構造を維持するか否かにより明らかに 生ずる測定值の差の解釈。第二に用いる基質液 の種類，特に電解質組成の差により生ずる測定 值の変動の解瀵を如何にするかにより事実の解 釈に誤を侵す危険が感じられる。独特の形態と 化学組成を内存せる蝸牛を対象とする時に注他 の組織と異つた注意が必要である。基本的倹討 の一つの試みとして，形態完全な膜螖牛に於て 内リンパ腔を開放する部位を変る事によつて生 ずる酸素消費量の相異を電解質組成の異なる基 質液の組合せの下に検討し，蝸牛化学現象の部 位的特性を知り且将来進展するであるうこの方 面の研究の資料を得ようとした。

実験動物には成熟モルモット，装置はワール ブルグ検圧計を使用した。基質には $0.2 \%$ ブド ウ糖添加の Krebs Ringer Phosphate Solution と, そのカリウムとナトリウムの比を, Smith の示した内リンパの組成と一致する様に調整し た液を使用した。実験材料をモルモット楇牛 で，膜様迷路を損傷しない即ち，内リンパを開 放さぜるものと，故意に内リンパを一部にて血 管条を経て開放したものとを用いた。実験成績 は附図の如くである。即ち暯螖牛が露出しただ けの場合，即ちその螖牛としての形態が完全で あり内リンパが基質と遮断され、て居れば，Krebs Ringer 液を基質とした時，酸素消費の一時 間值の平均は，湿重量 $1 \mathrm{mg}$ につき $18.3 \mu \mathrm{l}$ を示 す。一方内リンパ液に相当する液の時は平均 值, $11.6 \mu \mathrm{l}$ と減少が著明である。

次に膜蝸牛を，ラセン勒带，血管条を経て一一 部切開し，内リンパが基質と混合する様に内リ ンパ腔を開放した場合は非常に興味ある成績が 認められた。先ずKrebs Ringer 液中では，上 中部回転部にて開放すると，酸素消費現象は完 全に停止し，基礎回転で開放した時のみ，非開 放の時と殆んど同程度の平均值， $17.5 \mu 1$ と云う 值を示した。次に内リンパに相当する溶液中で は全く逆の成績となり，上中部回転で開放した 場合は, 非常に高い酸素消費量を示し平均值は $22.2 \mu 1$ であり，なかでも第三回転附近が最も值 が高い。しかるに基底部で開放した場合には， 平均值は $11.6 \mu \mathrm{l}$ と云う低い值を示した。之の事 実は多くの事を示唆するものと思われる。

\author{
水越 治 小田”雅義 \\ 吉弘 純一 (京府大)
}

螖牛内での音の受容機構, 或いは内リンパ腔 と周囲との異常な電位差の維持, 更には内リン パの高濃度カリウムの維持等に要するエネルギ 一は，すべて生化学的な呼吸作用に依つて産生 される事は疑論の余地はあるまい。Vorsteen の如く，呼吸系酵素の組織化学的検索のみによ り有毛細胞にも之の能力を具備していると推定 する事は過言と感ずる点が少くないが，血管条 にて必要エネルギーが生ずる事は 間違いあるま い。

Krebs Riner 液が内リンパ腔と流通せる時, 酸素消費は一般に低下し，且内リンパ含有率と 比し高、濃度のカリウム液を基質とする時に は，内リンパ腔を開放して流通せしめた時に高 濃度のカリウム液が存在する事と, 蝸牛の酸素 消費は平行的な現象と見分る事が出来る。換言 すれば, 内リンパの高濃度のカリウム維持に必 要なポンプ作用の如き生化学的現象には蝸牛で 消費される酸素の可成りの部分が利用されると む表現し得る。

ラセン靯帯，血管条を切開して内リンパ腔を 基質液に開放する時酸素消費量は変動するが, その開放部位が異る事により螖牛全体の酸素消 費量の大きく変動する事は，上記の如き生化学 的エネルギ一発生機構が蝸牛の各部位に於て均 一的なもので無い事を意味している。恐らく生 体内リンパ腔のカリウムイオン濃度は均一的な ものでなく，動的に各部に於て調節され，一定 の勾配を形成しているものと推定される。且開 放部位による変動の傾向が，Misrahy の示した D.C.電位の部分的勾配と一致しない点等を考 え合せると，K濃度と D.C.電位の間には直接 的な相関性は存在しない一つの根拠を示すもの と感ぜられる。

本実験のみによれば，高濃度のカリウム維持 には，蝸牛中部の血管条が重要であり，Kイオ ン濃度の流れは之の部を中心にした動的状態に あるとも考えられ得るが之の点は更に検討を要 する事が少くない。少くとも生体中では内リン パ組成, 或はイオン化率は螖牛各部で均一的で は無い事のみは断定し得るものと考える。従つ て䗁牛の生理状態, 或は病理状態を呼吸系の面 より追究する時には上記の特性を考慮に入れな ければ事実の把握に誤を扔かす，所が極めて多く なる事を指摘したい。 


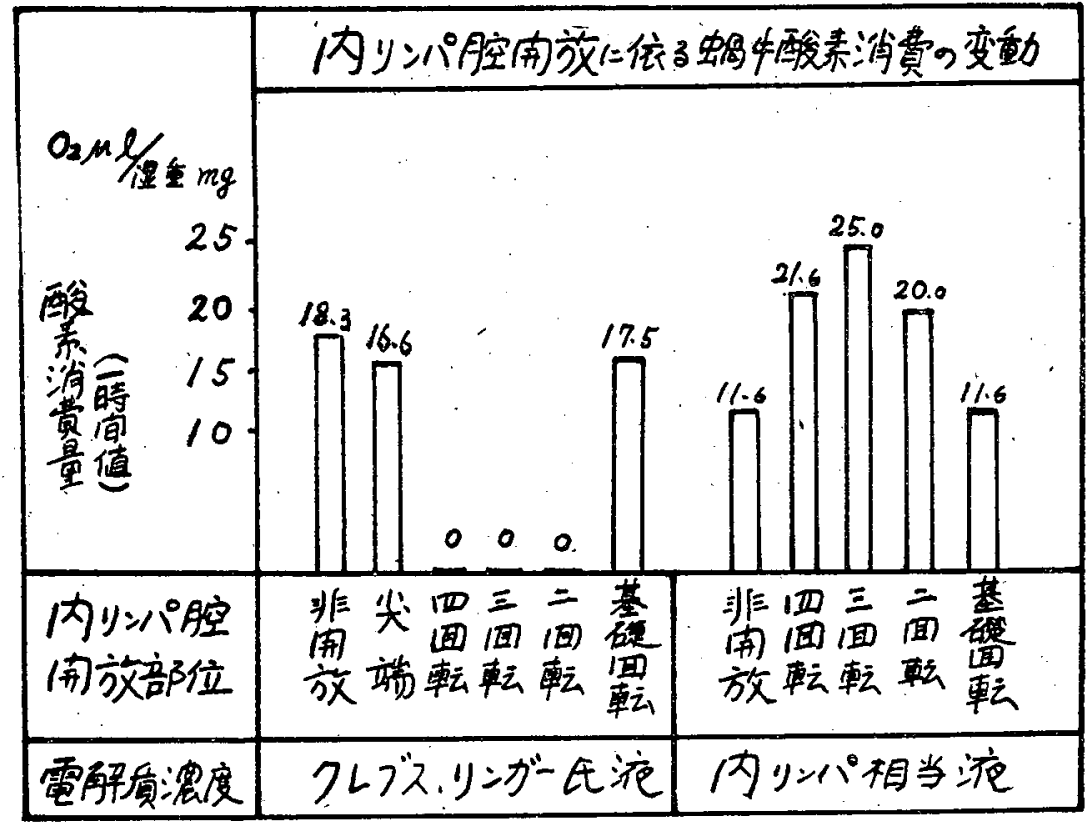

水越他論文附国

解糖呼吸系物盾の抗菌力に及ぼす影管

\begin{tabular}{|c|c|c|c|c|c|c|c|c|c|c|}
\hline $\operatorname{DHSM}(\gamma / c c)$ & 400 & 200 & 100 & 50 & 25 & 12.5 & 6.3 & 3.1 & 1.6 & 0.8 \\
\hline Control & - & - & - & 一 & 一 & \pm & + & + & +世 & t+t \\
\hline Glucose-6-P & - & 一 & 一 & - & - & + & $H$ & $m$ & +4 & t+t \\
\hline Pynuvate & - & - & - & - & - & + & + & $\mathrm{m}$ & $\#$ & H+ \\
\hline Suc & - & - & - & \pm & + & + & + & $\#$ & + & 世 \\
\hline KMI & 400 & 200 & 100 & 50 & 25 & 12.5 & 6.3 & 3.1 & 1.6 & 0.8 \\
\hline Control & - & - & - & - & + & + & + & + & \# & + \\
\hline Glucose-6-P & - & 一 & 一 & - & + & + & 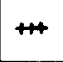 & $*$ & + & + \\
\hline Pyrurate & - & - & - & \pm & \pm & $\#$ & m & $m$ & $\#$ & + \\
\hline Succinate & - & - & \pm & + & H & H & 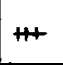 & $\omega$ & +1 & \# \\
\hline
\end{tabular}

中村他言侖文附表 